\title{
Urgensi Pembentukan Undang-Undang Digital Banking Bagi Perbankan Syariah Di Indonesia
}

\author{
Muhammad Urfi Amrillah \\ Magister Hukum Universitas Islam Indonesia Yogyakarta Indonesia \\ Jln. Cik Di Tiro No. 1 Yogyakarta Indonesia \\ urfiamrillah@gmail.com
}

\begin{abstract}
This study aims to determine the legal regulation of digital banking in Indonesia and the urgency of digital banking regulation for Islamic banking in Indonesia. This is a normative juridical research that uses a statutory approach. The results conclude that digital banking provisions are regulated in OJK Regulation No.12/POJK.03/2018 on the Implementation of Digital Banking Services by Commercial Banks in lieu of Law Number 7 of 1992 jo. Law Number 10 of 1998 on Banking does not regulate digital banking provisions. The urgency of digital banking regulations for Islamic banking in Indonesia can be viewed from several aspects, namely: first, the philosophical aspect, which are the special regulations related to digital banking for Islamic banking in Indonesia, that is mandated in Article 33 paragraphs (1) and (4) of the 1945 Constitution. Second, the sociological aspect, which is the case of a digital account burglary experienced by one of the customers as a result of the absence of strong regulations such as laws governing digital banking, especially for Islamic banking in Indonesia. Third, the juridical aspect, which is that digital banking is legally regulated in the OJK Regulation so that it has not been able to overcome the problems that occur, especially in the implementation of digital banking for Islamic banking, given the weakness of the binding power of the regulation.
\end{abstract}

Key Words: Digital banking; Financial Services Authority; sharia banking

\begin{abstract}
Abstrak
Penelitian ini bertujuan untuk mengetahui pengaturan hukum digital banking di Indonesia dan urgensi regulasi digital banking bagi perbankan syariah di Indonesia. Penelitian ini adalah penelitian yuridis normatif yang menggunakan pendekatan perundang-undangan. Hasil penelitian ini menyimpulkan bahwa, ketentuan perbankan digital diatur dalam Peraturan OJK No.12/POJK.03/2018 tentang Penyelenggaraan Layanan Perbankan Digital oleh Bank Umum mengingat Undang-Undang Nomor 7 Tahun 1992 jo. Undang-Undang Nomor 10 Tahun 1998 tentang Perbankan tidak mengatur ketentuan digital banking. Urgensi regulasi digital banking bagi perbankan syariah di Indonesia dapat ditinjau dari beberapa aspek yaitu, pertama, aspek filosofis yaitu regulasi khusus terkait digital banking bagi perbankan syariah di Indonesia merupakan amanat dalam Pasal 33 ayat (1) dan (4) Undang-Undang Dasar 1945. Kedua, aspek sosiologis, yaitu adanya kasus pembobolan rekening digital yang dialami oleh salah satu nasabah sebagai akibat dari belum adanya regulasi yang kuat seperti undang-undang dalam mengatur mengenai digital banking khususnya bagi perbankan syariah di Indonesia. Ketiga, aspek yuridis, yaitu secara yuridis digital banking hanya diatur dalam Peraturan OJK tersebut sehingga belum mampu mengatasi persoalan risiko yang terjadi khususnya pada implementasi digital banking bagi perbankan syariah mengingat lemahnya kekuatan mengikat Peraturan tersebut.
\end{abstract}

Kata-kata Kunci: Digital banking; otoritas jasa keuangan; perbankan syariah 


\section{Pendahuluan}

Bank syariah di Indonesia secara resmi diperkenalkan pada 1992 dan sejalan dengan diberlakukannya Undang-Undang Nomor 7 Tahun 1992 tentang Perbankan (UU Perbankan). Lahirnya undang-undang ini menandakan adanya kesepakatan rakyat dan bangsa Indonesia untuk menerapkan sistem perbankan ganda (dua banking system) di Indonesia. Tahapan ini merupakan tahapan perkenalan terhadap perbankan. ${ }^{1}$ Apabila kita melihat secara umum, kedudukan Undang-Undang No. 21 Tahun 2008 tentang Perbankan Syariah (UU Perbankan Syariah) merupakan lex spesialis dari UU Perbankan mengingat UU Perbankan Syariah merupakan undang-undang yang khusus mengatur perbankan syariah, sedangkan UU Perbankan hanya mengatur perbankan secara umum, baik perbankan syariah maupun perbankan konvensional. Salah satu asas perundangundangan adalah lex spesialis deragat lex generalis, yaitu undang-undang yang bersifat khusus mengesampingkan undang-undang yang bersifat umum. Dengan demikian, apabila dalam UU Perbankan Syariah ada pengaturan yang berbeda dengan yang diatur dalam UU Perbankan, landasan aturan yang digunakan adalah UU Perbankan Syariah. ${ }^{2}$

Tuntutan digitalisasi perbankan juga diperkuat oleh pergeseran kepemilikan bisnis yang saat ini didominasi oleh generasi milenial dan lebih menyukai kenyamanan transaksi online melalui platform digital. Terkait hal ini, jumlah pengguna internet di Indonesia mencapai 54,68 persen dari total populasi 262 Juta penduduk ${ }^{3}$ dimana 87 persennya merupakan pengguna aktif aplikasi chat dan 74,84 persen merupakan pengguna aktif aplikasi media sosial. Data tersebut mendorong bank untuk mengubah strategi pemasaran dari konvensional menjadi digital sehingga dapat meningkatkan literasi layanan perbankan digital. Urgensi proses transformasi perbankan juga didorong oleh bermunculnya pesaing baru, yaitu perusahaan penyedia jasa keuangan non perbankan atau biasa disebut fintech. Bisnis fintech mulai menggerus layanan perbankan karena berbagai kemudahan yang ditawarkan tanpa birokrasi yang rumit. ${ }^{4}$

\footnotetext{
Karnaen Perwataatmadja, Bank dan Asuransi Islam di Indonesia, Kencana, Jakarta, 2005, hlm. 1-3.

Neni Sri Imaniyati, "Perkembangan Regulasi Perbankan Syariah di Indonesia: Peluang dan Tantangan", Jurnal Ilmu Hukum, Volume 11, Nomor 1, diakses dalam https://ejournal.unisba.ac.id/index.php/ syiar_hukum/article/view/510, pada 1 November 2020, pukul 12.56 WIB, hlm. 30. Kominfo, Press Release No 53/HMKOMINFO/02/2018, diakses melalui https://kominfo.go.id/index.php/content/detail/12640/siaran-pers-no-53hmkominfo022018-tentang-jumlahpengguna-internet-2017-meningkat-kominfo-terus-lakukan-percepatanpembangunan-broadband/0/siaran_pers, 2018, dikutip melalui Shinta Winasis dan Styo Riyanto, “Transformasi Digital di Industri Perbankan Indonesia: Impak pada Stress Kerja Karyawan”, Iqtishadia, Jurnal Ekonomi dan Perbankan Syariah, Vol. 7, Nomor 1, 1 Juni 2020, hlm. 57.

${ }^{4}$ Shinta Winasis dan Styo Riyanto, Transformasi Digital di Industri Perbankan Indonesi..., Loc. it.
} 
Bank syariah harus mampu mengubah model pemasaran dan model manajemen bank syariah untuk menerapkan perbankan digital ini. Tantangan bagi bank syariah dalam mengembangkan perbankan digital ini yaitu keengganan nasabah yang diakibatkan oleh pengalaman buruk. Dengan demikian, pengembangan teori pemasaran layanan dalam perbankan digital membutuhkan pemahaman preferensi pelanggan dari kepuasan dan loyalitas pelanggan. ${ }^{5}$ Terkait hal ini, Otoritas Jasa Keuangan dalam siaran persnya mengatakan bahwa jumlah nasabah yang menggunakan layanan e-banking (SMS Banking, Phone Banking, Mobile Banking dan Internet Banking) melonjak 270 persen menjadi 50,4 juta pada 2016 dari 13,6 juta pada 2012. Selain itu, transaksi e-banking melonjak sebesar 169 persen menjadi 405,4 juta transaksi pada 2016 dai 150,8 juta transaksi pada $2012 .^{6}$

Pasal 20 ayat (1) poin f UU Perbankan Syariah menjelaskan bahwa ${ }^{7}$ menyelenggarakan kegiatan atau produk bank yang berdasarkan Prinsip Syariah dengan menggunakan sarana elektronik. Ayat kedua poin d pasal tersebut menyatakan bahwa menyelenggarakan kegiatan atau produk bank yang berdasarkan Prinsip Syariah dengan menggunakan sarana elektronik. UU Perbankan Syariah tidak menjelaskan secara terperinci pengertian tentang menyelenggarakan kegiatan atau produk bank berdasarkan pada prinsip syariah dengan menggunakan media elektronik sehingga dapat menimbulkan multitafsir terkait pemahaman pelaksanaan kegiatan perbankan syariah.

Selain itu, aturan-aturan yang berlaku dalam perbankan syariah hampir semua mengacu pada peraturan umum yang dibuat oleh Otoritas Jasa Keuangan saja, sedangkan dalam aturan Otoritas Jasa Keuangan tidak menjelaskan secara terperinci mengenai pengembangan perbankan syariah dalam digital banking. Oleh karena itu, perlu kiranya kejelasan mekanisme pelaksanaan kegiatan perbankan syariah berbasis digital untuk membedakan antara bank syariah dan bank konvensional. Hal ini dikarenakan akan berdampak pada pola kemajuan perbankan syariah sendiri, khususnya di Indonesia yang mayoritas muslim.

Menurut Gustav Radbruch, hukum harus mengandung 3 nilai identitas, yaitu: asas kepastian hukum (rechmatigheid) yang meninjau dari sudut yuridis,

5 C. I. Mbama and P. O. Ezepue. "Digital Banking, Customer Experience And Bank Financial Performance: UK Customers' Perceptions", International Journal of Bank Marketing, Volume 36, 2018, hlm. 230255, dikutip dari Vera Vebiana, Perbankan Digital, Pengalaman Pelanggan dan Kinerja Keuangan Bank Syariah, Industrial Research Workshop and National Seminar, Polban, 2018, hlm. 747.

${ }^{6}$ Otoritas Jasa Keuangan, Siaran Pers: OJK Terbitkan Panduan Penyelenggaraan Kantor Digital untuk Wujudkan Perbankan Digital di Indonesia, 19 Januari 2017, https://www.ojk.go.id/id/berita-dan-kegiatan/siaranpers/Pages/Siaran-Pers-OJK-Terbitkan-Panduan-Penyelenggaraan-Kantor-Digital-untuk-Wujudkan-PerbankanDigital-di-Indonesia.aspx, diakses 13 November 2020, pukul 17.00 WIB.

7 Pasal 20 ayat (1) poin $\mathrm{f}$ dan Pasal 20 ayat (2) poin d Undang-Undang Nomor 21 Tahun 2008 tentang Perbankan Syariah 
asas keadilan hukum (gerectigheit) yang meninjau dari sudut filosofis, dan asas kemanfaatan hukum (zwechmatigheid) atau doelmatigheid atau utility. Selain itu, berubahnya hukum karena adanya perkembangan zaman diikuti juga dengan adanya kebijakan pemimpin sebagai pemegang otoritas terhadap rakyat untuk membentuk satu aturan baru, memberikan kemaslahatan untuk masyarakat luas, dan memberikan kepastian hukum. Hal ini sejalan dengan kaidah fiqh yang yang erat kaitannya dengan pemerintahan ketika dilihat dari sudut pandang cakupannya yang luas adalah kaidah figh yang menyatakan bahwa kebijakan imam/pemerintah bagi rakyat harus berdasar maslahah. ${ }^{8}$ Artinya, kebijakan yang dikeluarkan oleh pemerintah selalu berorientasi terhadap perbaikan seluruh rakyatnya, mengingat tindakan dan kebijakan yang ditempuh, dan diambil oleh seorang untuk kepentingan bersama, bukan untuk kepentingan golongan tertentu saja atau bahkan untuk kepentingan diri pribadinya. ${ }^{9}$

\section{Rumusan Masalah}

Berdasarkan dari latar belakang di atas, rumusan masalah dalam penelitian ini adalah, pertama, bagaimana pengaturan hukum digital banking di Indonesia? Kedua, apa urgensi regulasi digital banking bagi perbankan syariah di Indonesia?

\section{Tujuan Penelitian}

Tujuan penelitian ini adalah, pertama, mengetahui pengaturan hukum digital banking di Indonesia. Kedua, mengetahui urgensi regulasi digital banking bagi perbankan syariah di Indonesia.

\section{Metode Penelitian}

Jenis penelitian ini adalah penelitian yuridis normatif yang memandang suatu hukum sebagai kaidah yang dapat menentukan apa yang kiranya boleh untuk dilakukan dan apa yang tidak boleh dilakukan. Kajian normatif mengkaji mengenai law in books. ${ }^{10}$ Penelitian hukum normatif memiliki cakupan berupa asas-asas hukum, sistematika hukum, peraturan perundang-undangan, perbandingan hukum, sejarah hukum, serta segala hal yang berkaitan dengan unsur-unsur pembaharuan hukum. ${ }^{11}$ Kajian ini dapat diartikan juga dengan

8 Toha Andiko, Ilmu Qawa'id Fiqhiyyah, Teras, Yogyakarta, 2011, hlm. 164.

${ }^{9}$ Abdul Mudjib, Kaidah-Kaidah Ilmu Fiqih, Kalam Mulia, Jakarta, 2005, hlm. 61.

${ }_{10}$ Achmad Ali dan Wiwie Heryani, Menjelajabi Kajian Empiris terhadap Hukum, Cetakan Pertama, Kencana, Jakarta, 2012, hlm. 1.

${ }^{11}$ Soerjono Soekanto dan Sri Mamudji, Peneliian Hukum Normatif, Suatu Tinjauan Singkat, Cetakan Pertama, PT. Raja Grafindo Persada, Jakarta, 2007, hlm. 14. 
meneliti bahan pustaka atau data-data primer dan sekunder, ${ }^{12}$ yang berkaitan dengan digital banking bagi perbankan syariah, seperti Undang-Undang Nomor 21 Tahun 2008 tentang Perbankan Syariah dan Peraturan Otoritas Jasa Keuangan Nomor 12/POJK.03/2018 tentang Penyelenggaraan Layanan Perbankan Digital oleh Bank Umum (POJK). Metode pengumpulan data penelitian ini menggunakan studi pustaka terhadap bahan-bahan hukum yang berupa bahan hukum primer, bahan hukum sekunder, ataupun bahan hukum tersier dan bisa juga berasal dari bahan non hukum. Penelusuran data yang dilakukan untuk menghimpun bahan-bahan tersebut dapat dilakukan melalui membaca, melihat, mendengarkan maupun melakukan penelusuran bahan hukum tersebut melalui buku, jurnal, atau internet. ${ }^{13}$

\section{Hasil Penelitian dan Pembahasan}

\section{Pengaturan Hukum Digital Banking di Indonesia}

Bank perli melakukan investasi jangka panjang dalam menerapkan perbankan digital untuk di masa yang akan datang mengingat layanan perbankan digital mampu menghemat biaya operasional, memberikan kemudahan dan kenyamanan bagi para nasabahnya, dan tentunya akan menggaet banyak nasabah baru yang berada pada usia produktif dan relatif muda. Saat ini, Indonesia melalui Otoritas Jasa Keuangan (OJK) telah memberikan rambu-rambu dalam implementasi perbankan digital yang dituangkan dalam Peraturan OJK No. 12/POJK.03/2018 tentang Penyelenggaraan Layanan Perbankan Digital oleh Bank Umum. Peraturan ini diprakarsai guna mendorong efektivitas, efisiensi, dan menciptakan kesinambungan pelayanan kepada nasabah. Selain itu, bank juga perlu meningkatkan kapabilitas diikuti dengan penyelarasan strategi bisnis yang tepat sasaran serta pemanfaatan perkembangan teknologi informasi secara lebih optimal.

Peraturan OJK tersebut telah mengatur layanan perbankan digital karena Undang-Undang Nomor 7 Tahun 1992 jo. Undang-Undang Nomor 10 Tahun 1998 tentang Perbankan (UU Perbankan) tidak mengatur ketentuan terkait digital banking. Penjelasan umum Peraturan OJK tersebut menerangkan bahwa aspek teknologi informasi menjadi aspek yang sangat penting mengingat semakin tinggi penggunaan perangkat gawai (mobile device) dan komputer sebagai media transaksi keuangan. Hal tersebut juga didukung dengan meningkatnya

12 Bambang Sungono, Metodologi Penelitian Hukum, PT. Raja Grafindo Persada, Jakarta, 2009, hlm. 189.

13 Mukti Fajar dan Yulianto Ahnad, Dualisme Penelitian Hukum Normatif dan Empiris, Pustaka Pelajar. Yogyakarta, 2010, hlm. 160. 
penggunaan jaringan internet di Indonesia yang diikuti dengan perluasan pembangunan infrastruktur jaringan internet. ${ }^{14}$

Penggunaan teknologi informasi menjadi salah satu prasyarat dalam penyediaan jasa keuangan oleh bank, baik melalui pengembangan infrastruktur pendukung secara mandiri maupun melalui kerja sama dengan mitra bank. Dengan memanfaatkan teknologi informasi, bank diharapkan dapat memberikan layanan kepada nasabah tanpa batasan tempat dan waktu, serta dengan biaya seminimal mungkin, yang kemudian mampu memberikan kenyamanan maksimal kepada nasabah sesuai dengan preferensi nasabah. Selanjutnya telah dijelaskan bahwa bank dapat menyelenggarakan layanan perbankan digital sebagaimana tertuang dalam Peraturan OJK tersebut. Aturan tersebut menjelaskan bahwa bank dapat menyelenggarakan layanan perbankan elektronik atau layanan perbankan digital dan bank yang menyelenggarakan layanan perbankan elektronik atau layanan perbankan digital, wajib menerapkan manajemen risiko, prinsip kehati-hatian, dan memenuhi ketentuan dalam Peraturan Otoritas Jasa Keuangan ini. ${ }^{15}$

Proses penyelenggaraan layanan perbankan elektronik atau layanan perbankan digital merupakan salah satu upaya bank dalam rangka memperluas akses keuangan masyarakat. Hal ini tentu akan meningkatkan layanan keuangan dan dapat dilakukan secara mandiri oleh nasabah serta mempermudah pengelolaan keuangan nasabah. Di sisi lain, bank juga harus menerapkan manajemen risiko dan prinsip-prinsip dasar dalam perbankan yang mengacu pada ketentuan Otoritas Jasa Keuangan. Didalam Peraturan OJK tersebut terdapat dua pemahaman aturan berbeda yaitu tentang layanan perbankan elektronik dan layanan perbankan digital sebagaimana disebutkan dalam Pasal 2 peraturan di atas. Selaras dengan itu, perbankan yang menyelenggarakan layanan perbankan elektronik yaitu dengan memanfaatkan saluran distribusi (delivery channel). ${ }^{16}$

Pasal 10 Peraturan OJK tersebut menegaskan bahwa ${ }^{17}$ layanan perbankan digital yang disediakan oleh bank adalah administrasi rekening, otorisasi transaksi, pengelolaan keuangan dan/atau pelayanan produk keuangan lain

14 Penjelasan Atas Peraturan Otoritas Jasa Keuangan Nomor 12/POJK.03/2018 tentang Penyelenggaraan Layanan Perbankan Digital oleh Bank Umum.

15 Pasal 2 ayat (1) dan (2) Peraturan Otoritas Jasa Keuangan Nomor 12/POJK.03/2018 tentang Penyelenggaraan Layanan Perbankan Digital oleh Bank Umum.

${ }^{16}$ Rati M. Palilati, "Perlindungan Hukum Konsumen Perbankan oleh Otoritas Jasa Keuangan", Jurnal IUS, Volume 4, Nomor 3, hlm. 50, dikutip dari Herdian Ayu Andreana Beru Tarigan dan Daminto Hartono Paulus, Perlindungan Hukum Terhadap Nasabah Atas Penyelenggaraan Layanan Perbankan Digital, Jurnal Pembangunan Hukum Indonesia, Program Studi Magister Ilmu Hukum, Fakultas Hukum Universitas Diponegoro, Volume 1, Nomor 3, 2019, hlm. 299.

17 Pasal 10 ayat (1) dan (2) Peraturan Otoritas Jasa Keuangan Nomor 12/POJK.03/2018 tentang Penyelenggaraan Layanan Perbankan Digital oleh Bank Umum. 
berdasarkan persetujuan Otoritas Jasa Keuangan. Selain itu, bank dalam menyediakan layanan perbankan digital tersebut wajib memanfaatkan data dan/atau informasi yang dapat dipertanggungjawabkan kebenarannya. Ketentuan Pasal 10 huruf a POJK menjelaskan bahwa administrasi rekening mencakup antara lain pembukaan rekening, pengkinian data nasabah, hingga penutupan rekening dengan memanfaatkan media elektronik. Rekening dapat berupa $^{18}$ rekening simpanan (prinsip syariah dengan akad mudharabah dan/atau wadi'ah), rekening kredit atau pembiayaan, dan/atau rekening administratif (pengajuan permohonan jaminan antara lain bank garansi, Letter of Credit (L/C), dan jaminan lain).

Penjelasan Pasal 10 huruf b POJK, ${ }^{19}$ yang dimaksudkan otorisasi transaksi mencakup transaksi keuangan dan/atau transaksi non-keuangan. Contoh otorisasi transaksi adalah bank menyediakan aplikasi mobile banking yang sudah dikembangkan dengan teknologi yang dapat membaca data suara nasabah dan nasabah memiliki smartphone yang dilengkapi dengan teknologi dan aplikasi pendukung penggunaan QR code dan/atau Near Field Communication (NFC). Penjelasan huruf c POJK, ${ }^{20}$ pengelolaan keuangan merupakan salah satu layanan yang disediakan oleh bank untuk membantu nasabah dalam menganalisis dan merencanakan penggunaan dana, sehingga nasabah dapat mengambil keputusan penggunaan dana secara lebih bijak. Pengelolaan keuangan meliputi perencanaan keuangan, eksekusi transaksi keuangan, dan konsultasi keuangan yang terkait dengan layanan perbankan.

Penjelasan Pasal 10 Peraturan OJK tersebut merupakan bagian dari layanan perbankan digital oleh bank. Apabila mengamati dalam proses penyelenggaraan layanan perbankan digital, bank yang menyelenggarakan layanan perbankan digital sebagaimana dimaksud dalam Pasal 7 harus memenuhi persyaratan sebagai berikut, ${ }^{21}$ pertama, memiliki peringkat profil risiko dengan peringkat 1 atau peringkat 2 berdasarkan penilaian tingkat kesehatan bank periode penilaian terakhir, kedua, memiliki infrastruktur teknologi informasi dan manajemen pengelolaan infrastruktur Teknologi Informasi yang memadai, dan ketiga, termasuk dalam kelompok bank umum berdasarkan kegiatan usaha yang paling

18 , Pasal 10 ayat (1) huruf a Penjelasan Atas Peraturan Otoritas Jasa Keuangan Nomor 12/POJK.03/2018 tentang Penyelenggaraan Layanan Perbankan Digital oleh Bank Umum

${ }_{19}$ Pasal 10 ayat (1) huruf b Penjelasan Atas Peraturan Otoritas Jasa Keuangan Nomor 12/POJK.03/2018 tentang Penyelenggaraan Layanan Perbankan Digital oleh Bank Umum

${ }^{20}$ Pasal 10 ayat (1) huruf c Penjelasan Atas Peraturan Otoritas Jasa Keuangan Nomor 12/POJK.03/2018 tentang Penyelenggaraan Layanan Perbankan Digital oleh Bank Umum

21 Pasal 18 Penjelasan Atas Peraturan Otoritas Jasa Keuangan Nomor 12/POJK.03/2018 tentang Penyelenggaraan Layanan Perbankan Digital oleh Bank Umum 
sedikit dapat melakukan kegiatan usaha layanan perbankan elektronik sebagaimana diatur dalam ketentuan Otoritas Jasa Keuangan.

Antonius $\mathrm{Harie}^{22}$ menyatakan bahwa OJK hanya memperbolehkan Bank Umum Kelompok Usaha (BUKU) II, III dan IV untuk dapat menerapkan aturan perbankan digital. Artinya, bank yang memiliki modal inti di bawah Rp 1 trilliun tidak dapat menerapkan digital banking. Sejalan juga dengan hal tersebut, OJK hanya memperbolehkan bank dengan profil resiko 2 (baik) dan 1 (sangat baik).23 Menurut pengamat Institute for Development of Economics (Indef) Bhima Yudistira, dikatakan bahwa saat ini belum ada kebutuhan untuk merancang regulasi baru untuk mengakomodasi payung hukum digital banking, terlebih regulasi yang sudah ada baru diterbitkan pada 2018. Akan tetapi, Bhima menggarisbawahi bahwa pemerintah perlu memperhatikan aspek keamanan dan pemanfaatan data untuk pihak ketiga agar dapat diatur lebih ketat.

Bhima menuturkan bahwa di sisi lain melihat bahwa tren bank digital mendorong lanskap persaingan baru di sektor perbankan. Menurutnya, bank yang berinvestasi terhadap digitalisasi akan memperoleh pangsa pasar lebih besar dibandingkan bank yang tetap beroperasi secara konvensional. Di samping itu, kebutuhan terhadap digital banking semakin besar seiring dengan pertumbuhan jumlah pengguna internet aktif di 2020 yang mencapai 175,4 juta orang. Artinya, perbankan diharapkan memberikan layanan yang lebih cepat dengan biaya terjangkau dan akses di manapun dan kapanpun. Jika bank digital terealisasi, dampaknya akan sangat besar, khususnya bagi kalangan milenial. Namun, bukan tanpa halangan bahwa perbankan juga dinilai perlu untuk melakukan edukasi untuk segmen pasar lain, seperti UMKM dan pedesaan. ${ }^{24}$

\section{Urgensi Regulasi Digital Banking Bagi Perbankan Syariah di Indonesia}

Peraturan OJK No.12/POJK.03/2018 menyebutkan bahwa bank yang dapat melakukan penyeleggaraan layanan perbankan digital adalah bank umum yang disebutkan dalam Undang-Undang Nomor 10 Tahun 1998 tentang Perbankan dan

22 Antonius Harie Prasetyo Moerdianto adalah direktur eksekutif berpengalaman dengan riwayat bekerja di industri jasa keuangan. Terampil dalam keterampilan analitis, perbankan, akuntansi, risiko kredit, dan anti pencucian uang. profesional riset yang kuat dengan gelar doktor ( $\mathrm{PhD}$ ) yang berfokus pada perbankan, manajemen keuangan, anti pencucian uang dari , Fakultas Ekonomi dan Bisnis, Universitas Indonesia, diakses dalam https://id.linkedin.com/in/antonius-harie-prasetyo-moerdianto-392bb610?challengeId=AQEmHHXoIXIowAAAXbXNyRsJklZhTSFsrjWCKAKnLJ0nqUHYvBQMrhZSPhHYmx9gB2p-TAZ-W-

sLVoWaFju_Qu5sm5eciHoOA\&submissionId=873ab81d-6d9d-5716-7511-dcc1c393c95e, tanggal 20 Desember 2020, pukul 02.21 WIB.

23 "OJK Keluarkan Payung Hukum Layanan Digital Banking, Zulfah Robbania", https://pojoksatu.id/pojok-bisnis/2018/09/28/ojk-keluarkan-payung-hukum-layanan-digital-banking/. diakses tanggal 28 Desember 2020, pukul 01.20 WIB.

24 "2020 Jadi Tahun Realisasi Bank Digital Indonesia, Corry Anestia", 27 Juli 2020, https://dailysocial.id/post/realiasi-bank-digital-indonesia-2020, diakses tanggal 28 Desember 2020, pukul 01.24 WIB. 
Bank Umum Syariah sebagaimana yang dimaksud dalam Undang-Undang Nomor 21 Tahun 2008 tentang Perbankan Syariah. Indonesia sebagai bagian negara yang menyetujui adanya perbankan digital perlu untuk melihat karakteristik dari perbankan digital itu sendiri sehingga dapat diketahui siapa yang berwenang mengatur, dimana letak peraturannya, dan kemudian akan tunduk pada peraturan apa saja nantinya perbankan digital ini.

Karakteristik perbankan digital adalah ${ }^{25}$ pertama, digital banking tidak lagi memerlukan kantor cabang, kedua, digital banking lebih dari sekedar aplikasi perbankan, dan ketiga, digital banking berbasis biometrik e-KTP Indonesia. Perbankan digital di Indonesia diawasi dan diatur oleh Otoritas Jasa Keuangan. Fungsi dari Otoritas Jasa Keuangan, sebagaimana diatur dalam Pasal 5 UndangUndang Nomor 21 Tahun 2011 tentang Otoritas Jasa Keuangan, adalah sebagai penyelenggara sistem pengaturan dan pengawasan yang terintegrasi terhadap keseluruhan kegiatan di dalam sektor jasa keuangan. Terkait hal ini, perbankan digital termasuk bagian dari jasa keuangan di sektor perbankan.

Otoritas Jasa Keuangan menyebutkan bahwa perbankan digital dapat diselenggarakan sesuai kebutuhan (customer experience) dan dilakukan secara mandiri sepenuhnya oleh nasabah dengan memperhatikan aspek pengamanan. Tentunya dalam penyelenggaraan layanan perbankan digital harus memenuhi beberapa persyaratan sebagai berikut, ${ }^{26}$ pertama, memiliki peringkat profil risiko dengan peringkat 1 atau peringkat 2 berdasarkan penilaian tingkat kesehatan bank periode penilaian terakhir, kedua, memiliki infrastruktur teknologi informasi dan manajemen pengelolaan infrastruktur teknologi yang memadai, dan ketiga, termasuk dalam kelompok bank umum berdasarkan kegiatan usaha yang paling sedikit dapat melakukan kegiatan usaha layanan perbankan elektronik sebagaimana diatur dalam ketentuan Otoritas Jasa Keuangan.

Operasional perbankan syariah berada dalam beberapa koridor prinsip yaitu, ${ }^{27}$ pertama, keadilan, berbagi keuntungan atas dasar penjualan riil sesuai kontribusi dan resiko masing-masing pihak. Kedua, kemitraan, yang berarti posisi nasabah investor (penyimpan dana) dan pengguna dana, serta lembaga keuangan itu sendiri, sejajar sebagai mitra usaha yang saling bersinergi untuk memperoleh keuntungan. Ketiga, transparansi, perbankan syariah akan memberikan laporan keuangan secara terbuka dan berkesinambungan agar nasabah investor dapat

25 “Three Things You Need do Know About Digital Banking”. 17 Desember 2018, https://www.dbs.com/newsroom/Three_Things_You_Need_to_Know_About_Digital_Banking, diakses 20 Desember 2020, pukul 22.36 WIB.

26 Pasal 18 Peraturan Otoritas Jasa Keuangan Nomor 12/POJK.03/2018 tentang Penyelenggaraan Layanan Perbankan Digital oleh Bank Umum,

27 Zainuddin Ali, Hukum Perbankan Syariah, Sinar Grafika, Jakarta, 2008, hlm. 58. 
mengetahui kondisi dananya. Dan keempat, universal, yang artinya tidak membedakan suku, agama, ras dan golongan dalam masyarakat sesuai dengan prinsip Islam sebagai rahmatan lil alamin.

Pengkajian atas UU Perbankan Syariah menunjukkan bahwa berbagai masalah yang belum dapat dicakup oleh peraturan sebelumnya sudah direspon dalam bentuk pengaturan yang lebih rinci. Namun, banyak juga aspek dari pengaturan yang ada dalam undang-undang ini yang sebenarnya sudah ada dalam berbagai peraturan perundang-undangan sebelumnya, yang kemudian diangkat dalam undang-undang ini. Tentu saja hal ini dilakukan ada tujuan untuk penguatan. Beberapa aspek penting yang cukup menonjol dalam undangundang tersebut diantaranya adalah ${ }^{28}$ persyaratan pendirian, bisnis/operasional perbankan, konversi, aspek prudensial, pengawasan syariah, dan penyelesaian sengketa (sebagian dibatalkan oleh Mahkamah Konstitusi Republik Indonesia). Jika dibandingkan dengan aturan yang sebelumnya, UU Perbankan Syariah ini jelas jauh lebih komprehensif. Akan tetapi, permasalahan saat ini yang berkaitan dengan digital banking belum diatur secara terperinci dalam undang-undang ini.

Orientasi perbankan Syariah di Indonesia tidak sebatas mengejar keuntungan saja, tetapi ada misi sosial yang selalu diupayakan oleh perbankan syariah guna menunjang kehidupan bermasyarakat dengan baik, dan tentunya membebaskan segala unsur riba yang selama ini diklaim bahwa bank konvensional menerapkan prinsip riba. Jika melihat penjelasan tersebut, dapat diartikan bahwa adanya kedudukan hukum memiliki pemahaman tentang subyek hukum ataupun obyek hukum yang berada. Dengan memiliki kedudukan, subyek hukum ataupun obyek hukum dapat melakukan tindakan dan wewenang sebagaimana statusnya. Dalam istilah bahasa latin, kedudukan hukum disebut locus standi yang memiliki makna bahwa suatu keadaan ketika suatu subyek hukum atau obyek hukum dianggap memenuhi persyaratan untuk mengajukan permohonan penyelesaian suatu sengketa yang terjadi. Kedudukan hukum biasanya ditunjukkan dengan cara sebagai berikut, pertama, suatu subyek hukum dirugikan oleh suatu peraturan dan kemudian menimbulkan peristiwa yang menjadi permasalahan. Peristiwa ini akan hilang bila pengadilan turun tangan. Kedua, suatu subyek hukum atau obyek hukum diberikan kedudukan hukum untuk melakukan tindakan yang diamanatkan melalui undang-undang.

Pemaparan di atas menunjukkan bahwa Peraturan OJK No.12/POJK.03/2018 dan Undang-Undang Nomor 21 Tahun 2008 memiliki kedudukan hukum yang sama dalam hal implementasi digital banking bagi

28 Agus Triyanta, Hukum Perbankan Syariah: Regulasi, Implementasi dan Formulasi Kepatuhannya Terhadap Prinsip-Prinsip Islam, Setara Press, Malang, 2016, hlm. 32. 
perbankan syariah, namun masih perlu dipahami lebih lanjut mengenai beberapa hal terkait dalam pengembangannya. Dalam proses penerapan perbankan digital, bank syariah tentu mengalami hambatan dan tantangan di antaranya adalah: ${ }^{29}$ pertama, keterbatasan suplai produk syariah. Kedua, keterbatasan akses akan produk keuangan syariah. Ketiga, belum optimalnya tingkat literasi keuangan syariah dan tingkat utililitas produk keuangan syariah. Keempat, keterbatasan sumber daya manusia. Kelima, perlunya optimalisasi koordinasi dengan para pemangku kepentingan. Keenam, perlunya kebijakan jasa keuangan yang selaras dan dapat saling mendukung perkembangan seluruh setir keuangan syariah.

Proses digitalisasi perbankan syariah adalah sebuah keniscayaan sehingga antisipasinya adalah legacy untuk bisa bertahan. ${ }^{30}$ Di sisi lain, kondisi perbankan syariah yang mendorong adanya penggunaan teknologi digital antara lain bahwa perbedaan antara konsep dan sistem perbankan syariah sebagaimana penjelasan di atas mengenai prinsip perbankan syariah, yang pada akhirnya masyarakat akan menganggap bahwa sistem perbankan syariah tidak menguntungkan dibandingkan dengan bank konvensional. Pernyataan ini selaras dengan Abdus Salam Dz yang menjelaskan bahwa masyarakat butuh literasi agar memiliki pemahaman yang mudah dan benar bahwa sistem perbankan syariah lebih menguntungkan daripada sistem konvensional. Hal ini dikarenakan literasi merupakan serangkaian proses atau aktivitas untuk meningkatkan pengetahuan (knowledge) dan menambah wawasan, keyakinan (confidence) dan keterampilan (skills) konsumen dan masyarakat luas sehingga mereka mampu mengelola keuangannya secara lebih baik. ${ }^{31}$

Pernyataan lain dijelaskan oleh Otoritas Jasa Keuangan, yang menyebutkan bahwa setidaknya ada tiga tantangan yang dihadapi dalam perbankan di Indonesia dalam pelayanan digital banking, yaitu evaluasi uji coba layanan, digital banking Bank Indonesia (BI) terkait dengan sistem informasi bank, dan ketersediaan jaringan dan edukasi serta perlindungan konsumen. ${ }^{32}$ Selain tantangan yang terkait dengan digital banking di atas, dalam praktek perbankan digital masih menghadapi juga berbagai hambatan yang membuat perkembangan ekonomi perbankan digital terganggu, khususnya bagi perbankan syariah di Indonesia yaitu, pertama, infrastruktur jaringan yang kurang luas sehingga belum dapat diakses semua orang, kedua, masih rendahnya minat masyarakat Indonesia

${ }^{29}$ Abdus Salam Dz, "Inklusi Keuangan Perbankan Syariah Berbasis Digital Banking: Optimalisasi dan Tantangan”, Jurnal Al-Amwal, Volume 10, Nomor 1, 2018, hlm. 75.

30 Ibid., hlm. 75.

31 Ibid., hlm. 76.

32 "OJK: Ada Tiga Tantangan Perbankan dalam Pelayanan Digital Banking", https://www.wartaekonomi.co.id/read30398/ojk-ada-tiga-tantangan-perbankan-dalam-pelayanan-digitalbanking. diakses pada tanggal 29 Desember 2020, pukul 01.00 WIB. 
yang melakukan kegiatan ekonomi digital, baru sekitar 35\% masyarakat Indonesia yang melakukan transaksi digital keuangan. Kontribusi bisnis di sektor digital masih minim terhadap Produk Domestik Bruto (PDB). Ketiga, bagi para CEO bank, hal ini terjadi saat mengambil kepemimpinan untuk pengembangan dan pelaksanaan program perubahan menyeluruh yang secara bersamaan membahas budaya, sistem, dan kemampuan yang diperlukan. ${ }^{33}$

Perkembangan teknologi yang semakin canggih membuat masalah keamanan dan kendala menjadi keluhan yang cukup signifikan, sebagai contoh saat nasabah melakukan transfer uang tetapi uang tidak masuk atau belum sampai pada nasabah yang dituju. Hal ini tentunya mengandung unsur ketidakpastian atau ketidakjelasan (gharar) yang tentunya akan bertentangan dengan prinsip dari perbankan syariah. Di samping itu, kejahatan yang paling sering terjadi yaitu pencurian identitas atau phising. Phising (password harvesting fishing) adalah tindak kejahatan penipuan dengan memanfaatkan email palsu atau situs website palsu yang bertujuan untuk mengelabui user lain. Pemanfaatan email palsu atau website palsu ini ditujukan untuk mendapatkan data user tersebut. Penggunaan data user seringkali untuk mengirim email yang seolah-olah berasal dari sebuah perusahaan resmi, misalnya bank dengan tujuan untuk mendapatkan data-data pribadi seseorang, misalnya User ID, PIN, nomor rekening, nomor kartu kredit dan sebagainya. ${ }^{34}$

Beberapa contoh kasus dalam implentasi digital banking yaitu, pembobolan rekening digital yang dialami oleh salah satu nasabah PT Bank BTPN Tbk yaitu dengan menggunakan akun rekening jenius. ${ }^{35}$ Nasabah yang bernama Anggita Wahyuningtyas mengalami kejadian pembobolan dengan jumlah di atas Rp. 50.000.000,00. Pembobolan itu berawal dari adanya panggilan telepon dari pihak penipu yang seolah-olah bertindak sebagai call center Jenius sekitar 2 pekan sebelumnya, tepatnya pada 7 September 2020. Isi dari panggilan tersebut menyebutkan adanya pembaruan sistem dan ada penggantian kartu ATM, yang pada akhirnya korban menberikn data dirinya. Hanya dalam hitungan menit, pelaku mampu menyedot uang milik korban dan kemudian mentransfer ke rekening yang juga sama-sama Jenius atas nama Lutfi Putri Mardiana. Setelah kemudian dilacak ternyata pemilik rekening tersebut tinggal di Lampung dan

33 Abdus Salam Dz, "Inklusi Keuangan ..., Op. Cit., hlm. 77.

34 Andi Hamzah, Aspek-Aspek Pidana di Bidang Komputer, Sinar Grafika, Jakarta, 2005, hlm. 56, sebagaimana diikutip dari Hilman Mursidi, "Pertanggungjawaban Pidana Terhadap Pelaku Tindak Pidana Cyber Crime Phising (Studi Kasus Putusan Pengadilan Negeri Medan Nomor: 3006/Pid.Sus/2017/PN.Mdn", Skripsi, Fakultas Hukum Universitas Sriwijaya Palembang, 2019, hlm. 14.

35 Finansial Bisnis, “Ada Pembobolan Rekening Digital, Ini Kata BTPN Soal Keamanan Akun Jenius, M. Richard”, diakses pada https://finansial.bisnis.com/read/20200921/90/1294614/ada-pembobolan-rekeningdigital-ini-kata-btpn-soal-keamanan-akun-jenius 1 Januari 2021, pukul 03.19 WIB. 
mengaku rekeningnya sedang dihack oleh orang yang tidak dikenal. Pada hari yang sama, uang hasil curian tersebut milik Angguta sudah dipindahkan ke dua rekening lain. Korban sudah melaporkan kepada pihak BTPN, Otoritas Jasa Keuangan (OJK), dan pihak kepolisian. Namun, pelaku belum mampu terlacak keberadaannya.

Kesinambungan antara kasus di atas dengan perbankan syariah adalah cakupan prinsip kehati-hatian, yang diatur dalam Pasal 35 ayat (1) UU Perbankan Syariah, yang tentunya di sini menyangkut banyak aspek, baik dalam tata kelola maupun dalam pengamanan bagi para nasabah. Hal ini sejalan dengan Pasal 21 Peraturan OJK No.12/POJK.03/2018 yang menjelaskan bahwa, (1) Bank penyelenggara layanan perbankan elektronik atau layanan perbankan digital wajib menerapkan prinsip perlindungan konsumen sebagaimana dimaksud dalam ketentuan peraturan perundang-undangan mengenai perlindungan konsumen sektor jasa keuangan, (2) Bank penyelenggara layanan perbankan digital wajib memiliki fungsi dan mekanisme penanganan setiap pertanyaan dan/atau pengaduan dari nasabah yang beroperasi selama 24 (dua puluh empat) jam dalam sehari, (3) Mekanisme dan tata cara penerapan prinsip perlindungan konsumen tersebut mengacu pada ketentuan peraturan perundang-undangan mengenai pelindungan konsumen sektor jasa keuangan.

Didalam implementasi digital bangking tentu masih banyak celah yang mampu disalahgunakan oleh pihak-pihak yang tidak bertanggung jawab, jika tanpa adanya pengawasan, penyelenggaraan digital banking tentunya akan banyak mengalami risiko yang sangat besar dan pasti korbannya adalah nasabah dari perbankan. Otoritas Jasa Keuangan tidak akan pernah membiarkan tindakan tersebut. Untuk mengawal proses implementasi digital banking Otoritas Jasa Keuangan membentuk tim Taskforce Digital Banking untuk melakukan kajian terhadap digital banking dan pada waktunya akan menyampaikan rekomendasi mengenai guideline tentang pendapat digital banking oleh perbankan Indonesia. ${ }^{36}$

Otoritas Jasa Keuangan melihat adanya beberapa hal yang perlu mendapat perhatian untuk pengembangan layanan perbankan digital, yaitu: Pertama, pentingnya menggunakan singlet identity (misalnya e-KTP) bagi perbankan sebagai basis data nasabah. Kedua, perbankan perlu mempersiapkan infrastruktur teknologi informasi dan infrastruktur lainnya yang handal, menerapkan risk manajemen yang baik dan modal bisnis yang sesuai dengan kebutuhan nasabah dalam hal bank memasuki bisnis digital banking. Ketiga, perlu standarisasi dan

36 Siaran Pers: OJK Dorong Bank Optimalkan Layanan Digital, https://www.ojk.go.id/id/kanal/ perbankan/berita-dan-kegiatan/siaran-pers/Pages/Siaran-Pers-OJK-Dorong-Bank-Optimalkan-LayananDigital.aspx. Diakses 02 Januari 2021, Pukul 01.08 WIB. 
peningkatan kedisiplinan implementasi SOP telco khususnya pada saat penggantian SIM card nasabah untuk mendukung layanan digital banking. Keempat, peningkatan pengamanan. Penerapan digital banking menyebabkan pintu masuk bagi cyber crime menjadi lebih terbuka, sehingga salah satu pengamanan melalui digital certificate dari certificate authority serta penerapan standar keamanan yang memadai terhadap mitra bank sesuai risk appetite bank. Kelima, Otoritas Jasa Keuangan akan melakukan penyesuaian sejumlah regulasi, antara lain terkait dengan kewajiban pertemuan tatap muka saat pembukaan rekening di bank, dengan mengacu pada prinsip-prinsip dasar proses identifikasi, verifikasi dan monitoring transaksi keuangan nasabah.

Berdasarkan gambaran data di atas setidaknya ada beberapa langkah yang dapat dilakukan oleh perbankan syariah sebagai ikhtiar untuk kemudian dapat mengembangkan digital banking, langkah tersebut kiranya menjadi penting yaitu: user friendly, hal ini tentu harus dilakukan oleh perusahan perbankan digital khususnya perbankan syariah, di mana perusahaan harus memberikan kesan terbaiknya kepada konsumen saat menggunakan jasanya. Hal ini tentu akan sangat berpengaruh karena memudahkan konsumen berpaling pada perusahaan lain apabila mereka merasa dirugikan baik dari segi pelayanan ataupun fasilitas yang disediakan. Cyber security, tentu ini menjadi tolak ukur utama dalam dunia perbankan, di mana perbankan harus mampu bekerja sama dengan pemerintah dalam memberikan keamanan yang maksimal kepada para nasabah saat mereka melakukan transaksi. Database, perusahaan perbankan harus mempunyai data para nasabah secara jelas, resmi dan terperinci agar nantinya dapat menganalisis data tersebut sesuai dengan kebutuhan, perilaku dan keinginan konsumen dalam menggunakan jasa layanan perbankan. Integrasi, perusahaan perbankan harus mampu menghubungkan kebutuhan online maupun offline dan hal inilah yang menjadi penunjang terlaksananya digital banking bagi perbankan syariah di Indonesia. DNA digital, perusahaan perbankan harus sudah memulai untuk membangun sebuah ekosistem DNA digital guna melakukan validasi data karena tentunya dalam pelaksanaan layanan perbankan digital pihak nasabah dan bank tidak bertemu face to face dalam melakukan transaksi. Hal ini juga bertujuan sebagai alat pengaman kevalidan data pemilik.

Keadaan demkian, tentu hal tersebut akan sejalan dengan konsep maslahah mursalah apabila betul-betul diterapkan guna kepentingan umum. Hal itu sejalan dengan prinsip meraih kemaslahatan dan menolak kemudharatan. ${ }^{37}$ Selain itu, hal itu juga selaras dengan prinsip bahwa perhatian syara' terhadap larangan lebih besar daripada perhatian syara' terhadap apa-apa yang diperhatikan.

${ }^{37}$ Abd. Haq, et.al, Formulasi Nalar Figh Telaah Konseptual, Khalista, Surabaya, 2006, hlm. 237. 
Apabila dalam suatu perkara terlihat adanya manfaat, namun didalamnya juga terdapat mafsadah, maka haruslah didahulukan menghilangkan mafsadah atau kerusakan, karena kerusakan dapat meluas dan menjalar kemana-mana, sehingga mengakibatkan kerusakan yang lebih besar.

Ada beberapa kriteria tertentu yang harus dijadikan ukuran dalam membatasi akal dalam menggunakan konsep ini, ${ }^{38}$ khususnya dalam implementasi digital banking bagi perbankan syariah di Indonesia, antara lain yaitu maslahah tersebut harus bersifat ma'qul (reasonable) dan relevan (munasib) dengan kasus hukum yang memang sudah ditetapkan oleh nusus. Implementasi peraturan harus layak dan pantas artinya memberikan gambaran yang jelas dalam sebuah aturan untuk menerapkan digital banking bagi perbankan syariah di Indonesia guna menekan terjadinya kasus-kasus baru. Maslahah tersebut harus dapat diterima oleh pemikiran rasional. Dalam penerapannya sebuah hukum haruslah mampu diterima masyarakat luas agar nantinya tidak menimbulkan sebuah penafsiran baru yang dapat menjadikan salah pemahaman dalam implementasinya. Maslahah tersebut harus sesuai dengan maksud syari' dalam menetapkan hukum dan tidak boleh bertentangan dengan nusus, baik dengan dalil-dalil tekstual atau dasar-dasar pemikiran substansialnya. Penjelasan tersebut menunjukkan bahwa perbankan syariah memperhatikan celah yang terjadi dan menggunakan dasar maslahah mursalah untuk melaksanakan kepentingan umum khususnya dalam ranah perbankan digital bagi perbankan Syariah di Indonesia.

\section{Penutup}

Berdasarkan hasil penelitian yang telah diuraikan pada bab-bab terdahulu dapat disimpulkan sebagai berikut:

1. Saat ini, Indonesia melalui Otoritas Jasa Keuangan telah memberikan ramburambu dalam implementasi perbankan digital yang dituangkan dalam Peraturan OJK No.12/POJK.03/2018 tentang Penyelenggaraan Layanan Perbankan Digital oleh Bank Umum. Peraturan ini diprakarsai guna mendorong efektivitas, efisiensi, dan menciptakan kesinambungan pelayanan kepada nasabah. Hal ini disebabkan karena Undang-Undang Nomor 7 Tahun 1992 jo. Undang-Undang Nomor 10 Tahun 1998 tentang Perbankan tidak mengatur ketentuan digital banking.

2. Urgensi pembentukan regulasi digital banking bagi perbankan syariah di Indonesia dalam bentuk undang-undang dapat ditinjau dari beberapa aspek berikut, pertama, aspek filosofis, yaitu regulasi khusus terkait digital banking

\footnotetext{
38 Ahmad Khusairi, Evolusi Ushul Fiqh: Konsep dan PengembanganMetode Hukum Islam, Pustaka Ilmu, Yogyakarta, 2013, hlm. 83.
} 
bagi perbankan syariah di Indonesia merupakan amanat dalam Pasal 33 ayat (1) dan (4) Undang-Undang Dasar 1945 mengingat pesatnya perkembangan teknologi informasi dapat digunakan untuk mengembangkan industri keuangan dapat mendorong tumbuhnya alternatif layanan perbankan secara masif. Kedua, aspek sosiologis, yaitu adanya kasus pembobolan rekening digital yang dialami oleh salah satu nasabah sebagai akibat dari belum adanya regulasi yang kuat seperti undang-undang dalam mengatur mengenai digital banking khususnya bagi perbankan syariah di Indonesia. Ketiga, aspek yuridis, yaitu secara yuridis digital banking hanya diatur dalam Peraturan OJK tersebut sehingga belum mampu mengatasi persoalan risiko yang terjadi khususnya pada implementasi digital banking bagi perbankan syariah mengingat lemahnya kekuatan mengikat Peraturan tersebut.

\section{Daftar Pustaka}

\section{Buku}

Ali, Achmad dan Wiwie Heryani, Menjelajahi Kajian Empiris terhadap Hukum, Cetakan Pertama, Kencana, Jakarta, 2012.

Ali, Zainuddin, Hukum Perbankan Syariah, Sinar Grafika, Jakarta, 2008.

Andiko, Toha, Ilmu Qawa'id Fiqhiyyah, Yogyakarta: Teras, 2011.

Fajar, Mukti dan Yulianto Ahnad, Dualisme Penelitian Hukum Normatif dan Empiris, Pustaka Pelajar, Yogyakarta, 2010.

Haq, Abd., et.al, Formulasi Nalar Fiqh Telaah Konseptual, Khalista, Surabaya, 2006.

Khusairi, Ahmad, Evolusi Ushul Fiqh: Konsep dan PengembanganMetode Hukum Islam, Pustaka Ilmu, Yogyakarta, 2013.

Mudjib, Abdul, Kaidah-Kaidah Ilmu Fiqih, Kalam Mulia, Jakarta, 2005.

Perwataatmadja, Karnaen, Bank dan Asuransi Islam di Indonesia, Kencana, Jakarta, 2005.

Soekanto, Soerjono dan Sri Mamudji, Peneliian Hukum Normatif, Suatu Tinjauan Singkat, Cetakan Pertama, PT. Raja Grafindo Persada, Jakarta, 2007.

Sungono, Bambang, Metodologi Penelitian Hukum, Jakarta: PT. Raja Grafindo Persada, 2009.

Triyanta, Agus, Hukum Perbankan Syariah: Regulasi, Implementasi dan Formulasi Kepatuhannya Terhadap Prinsip-Prinsip Islam, Setara Press, Malang, 2016.

\section{Jurnal}

Dz, Abdus Salam, "Inklusi Keuangan Perbankan Syariah Berbasis Digital Banking: Optimalisasi dan Tantangan", Jurnal Al-Amwal, Volume 10, Nomor 1, 2018.

Imaniyati, Neni Sri, "Perkembangan Regulasi Perbankan Syariah di Indonesia: Peluang dan Tantangan", Jurnal Ilmu Hukum, Volume 11, Nomor 1, 
sebagaimana dikutip dalam https://ejournal.unisba.ac.id/index.php/ syiar_hukum/article/view/510

Tarigan, Herdian Ayu Andreana Beru dan Daminto Hartono Paulus, "Perlindungan Hukum Terhadap Nasabah Atas Penyelenggaraan Layanan Perbankan Digital", Jurnal Pembangunan Hukum Indonesia, Volume 1. Nomor 3, Program Studi Magister Ilmu Hukum, Fakultas Hukum Universitas Diponegoro, 2019.

Vebiana, Vera, "Perbankan Digital, Pengalaman Pelanggan dan Kinerja Keuangan Bank Syariah", Industrial Research Workshop and National Seminar, Polban, 2018.

Winasis, Shinta dan Styo Riyanto, "Transformasi Digital di Industri Perbankan Indonesia: Impak pada Stress Kerja Karyawan", Jurnal Ekonomi dan Perbankan Syariah, Volume 7, Nomor 1, Iqtishadia, 2020.

\section{Hasil Penelitian/Tugas Akhir}

Mursidi, Hilman, "Pertanggungjawaban Pidana Terhadap Pelaku Tindak Pidana Cyber Crime Phising (Studi Kasus Putusan Pengadilan Negeri Medan Nomor: 3006/Pid.Sus/2017/PN.Mdn)", Skripsi, Fakultas Hukum Universitas Sriwijaya Palembang, 2019.

\section{Internet}

Anestia, Corry "2020 Jadi Tahun Realisasi Bank Digital Indonesia", diakses pada https:// dailysocial.id/post/realiasi-bank-digital-indonesia-2020

DBS Bank, "Three Things You Need do Know About Digital Banking" https://www.dbs.com/newsroom/Three_Things_You_Need_to_Know_ About_Digital_Banking. Diakses 20 Desember 2020.

Finansial Bisnis, "Ada Pembobolan Rekening Digital, Ini Kata BTPN Soal Keamanan Akun Jenius", https://finansial.bisnis.com/read/20200921/ 90/1294614/ada-pembobolan-rekening-digital-ini-kata-btpn-soalkeamanan-akun-jenius.

Kominfo, "Press Release No 53/HMKOMINFO/02/2018", diakses melalui https:// kominfo.go.id/index.php/content/detail/12640/siaran-pers-no53hmkominfo022018-tentang-jumlah-pengguna-internet-2017-meningkatkominfo-terus-lakukan-percepatanpembangunanbroadband/0/siaran_pers.

Otoritas Jasa Keuangan, "Siaran Pers: OJK Dorong Bank Optimalkan Layanan Digital", https://www.ojk.go.id/id/kanal/perbankan/berita-dankegiatan/siaran-pers/Pages/Siaran-Pers-OJK-Dorong-Bank-OptimalkanLayanan-Digital.aspx.

Otoritas Jasa Keuangan, "Siaran Pers: OJK Terbitkan Panduan Penyelenggaraan Kantor Digital Untuk Wujudkan Perbankan Digital di Indonesia", diakses https:/ / www.ojk.go.id/id/berita-dan-kegiatan/siaranpers/Pages/Siaran-Pers-OJK-Terbitkan-Panduan-PenyelenggaraanKantor-Digital-untuk-Wujudkan-Perbankan-Digital-di-Indonesia.aspx. 
Pojok Bisnis, "OJK Keluarkan Payung Hukum Layanan Digital Banking”, https: / / pojoksatu.id/pojok-bisnis/2018/09/28/ojk-keluarkan-payunghukum-layanan-digital-banking/.

Warta Ekonomi, "OJK: Ada Tiga Tantangan Perbankan Dalam Pelayanan Digital Banking", https://www.wartaekonomi.co.id/read30398/ojk-ada-tigatantangan-perbankan-dalam-pelayanan-digital-banking.

\section{Peraturan Perundang-Undangan}

Undang-Undang Nomor 21 Tahun 2008 Tentang Perbankan Syariah

Peraturan Otoritas Jasa Keuangan Nomor 12/POJK.03/2018 tentang Penyelenggaraan Layanan Perbankan Digital Oleh Bank Umum 